\title{
Growth and Economic Performance of Broiler Chickens Fed on Graded Levels of Canola Meal with or without Multi-Enzyme Supplementation
}

\author{
Hamada A. Ahmed ${ }^{1}$, Reham Abou-Elkhair ${ }^{2}$, Sara A. Ketkat ${ }^{3}$ \& Shaimaa Selim ${ }^{2,4}$ \\ ${ }^{1}$ Department of Nutrition and Clinical Nutrition, Faculty of Veterinary Medicine, Damanhour University, Egypt \\ ${ }^{2}$ Department of Nutrition and Clinical Nutrition, Faculty of Veterinary Medicine, Sadat City University, Egypt \\ ${ }^{3}$ Department of Animal Husbandry and Animal Wealth Development, Faculty of Veterinary Medicine, \\ Alexandria University, Egypt \\ ${ }^{4}$ Department of Agricultural Sciences, Faculty of Agriculture and Forestry, Helsinki University, Finland \\ Correspondence: Shaimaa Selim, Department of Agricultural Sciences, P.O. Box 28, FI-00014, University of \\ Helsinki, Finland. Tel: 358-045-306-2009. E-mail: shaimaa.selim@helsinki.fi
}

Received: February 25, 2015 Accepted: March 25, 2015 Online Published: May 15, 2015

doi:10.5539/jas.v7n6p137 URL: http://dx.doi.org/10.5539/jas.v7n6p137

\begin{abstract}
Canola meal $(\mathrm{CM})$ is commonly used in poultry diets; however, its use is limited due to anti-nutritive factors. Therefore, this study was conducted to evaluate the effects of feeding various levels of canola meal (CM) with or without multi-enzyme supplement on broiler chickens. Four levels of CM $(0,5,10$ and 20\%) were used with or without multi-enzyme ( 0 or $300 \mathrm{~g} /$ ton of diet) in a factorial design $4 \times 2$ in 8 dietary combinations. During the experimental period ( $0-42 \mathrm{~d}$ of age), inclusion of $\mathrm{CM}$ at a level of 5 and $10 \%$ without multi-enzyme and at a level of $20 \%$ with or without multi-enzyme decreased body weight gain and gain:feed ratio compared to control $(\mathrm{CON} ; \mathrm{P}<0.05)$. However, there was no difference in the final body weight at day 42 of age between the groups. No differences were found in carcass characteristics between treatments. Inclusion of CM in broiler diet decreased serum antibody titer at $42 \mathrm{~d}$ of age compared to the control and enzyme-supplemented CM groups $(\mathrm{P}<$ 0.05). Inclusion of CM with multi-enzyme supplement decreased serum total cholesterol, total triglyceride and glutamate oxaloacetate transaminase compared to CON and enzyme-unsupplemented groups $(\mathrm{P}<0.05)$. Diets supplemented with CM had higher serum creatinine than CON and enzyme-supplemented CM groups $(\mathrm{P}<0.05)$. Lower serum triiodothyronine in broilers fed diet supplemented with 10 or $20 \% \mathrm{CM}$ was noticed $(\mathrm{P}<0.05)$. CM with multi-enzyme supplementation to broiler ration showed a slight increase in net revenue.
\end{abstract}

Keywords: canola, chicken, enzyme, growth, immunity, thyroid

\section{Introduction}

Soybean meal (SBM) is the commonly used vegetable proteins in poultry diets in Egypt. Presently, the possibilities of using canola meal (CM) in place of SBM have emerged as a topic of increasing concern to the researchers. CM contains approximately $40 \%$ crude protein and has a well-balanced amino acid profile, as well as high levels of sulfur-containing amino acids compared to SBM (Bell, 1993; Newkirk, 2009). Its nutritive value, however, is limited in chicken diets by the presence of a number of anti-nutritive factors, including non-starch polysaccharides (NSP) and high fiber content (Bell, 1993; Kocher et al., 2000).

CM has approximately 2.5\% $\alpha$-galacto-oligosaccharides and 18\% NSP (Bell, 1993). These NSPs, including cellulose, $\beta$-glucans, arabinoxylans and pectins, may increase the viscosity of digesta and reduce nitrogen digestion and absorption (Annison, 1991), and consequently poor growth performance. Canola, although, has a relatively low level of glucosinolates (GLS, $<30 \mu \mathrm{mol} / \mathrm{g}$ ), the GLS content is still considered to limit its use in poultry and monogastric animals. Glucosinolates have adverse effects on metabolism and growth by interfering with thyroid hormone synthesis, causing liver and kidney damage, leg problems and appetite depression (Tripathi \& Mishra, 2007). The use of higher amount of CM in place of SBM has been associated with reduced performance in layers and broilers (Ikegami et al., 1990). Additionally, inclusion of CM at a level of $20 \%$ in poultry diets has been shown to reduce apparent metabolizable energy (Mushtaq et al., 2007), and nutrient digestibility (Slominski \& Campbell, 1990). Min et al. (2009) reported that increasing levels of CM in broiler starter diet had adverse effects on feed intake and body weight gain. Khajali et al. (2011) reported that carcass 
yield was reduced when SBM was substituted with CM in broilers. In turkeys, Mikulski et al. (2012) found that an inclusion of CM up to $120 \mathrm{~g} / \mathrm{kg}$ did not alter the fundamental characteristics of meat. Recently, Gopinger et al. (2014) observed that birds fed with 0 and $10 \% \mathrm{CM}$ had higher breast weight than the ones fed $40 \% \mathrm{CM}$.

The successful incorporation of enzyme supplementation in cereal-based diets (Chesson, 1993), has stimulated concern in the application of enzymes to vegetable protein components in poultry diets. The use of feed enzymes has a greater potential effect in poultry diets, particularly which contain anti-nutritional factors. The NSPs in feed stuffs are now considered the main target of commercial feed enzymes. Targeting CM with exogenous feed enzymes may be more challenging in poultry diets. Previous studies (Simbaya et al., 1996; Kocher et al., 2000, 2001) reported that inclusion of commercial enzyme complexes did not affect growth performance when added to poultry diet with high levels of CM. On the contrary, other studies (Slominski \& Campbell, 1990; Campbell et al., 2001; Sariçiçek et al., 2005) observed that a multi-enzyme supplementation to CM based diets improved the quality of CM.

Therefore, the objective of the present study was to determine the effects of feeding different levels of $\mathrm{CM}(5,10$, $20 \%$ ) with or without multi-enzyme supplement ( $\beta$-mannanase, xylanase, $\beta$-glucanase, $\alpha$-amylase, pectinase, phytase, proteases, lipase, amyloglycosidase, hemicellulose, acid phytase, acid phosphatase and pentosanase) on growth performance, carcass traits, blood parameters and humoral immune response in broiler chickens. The hypothesis was that enzyme-supplemented diets containing CM improves growth performance and humoral immune response compared with unsupplemented diets.

\section{Material and Methods}

\subsection{Birds, Experimental Design and Husbandry}

This study was carried out in strict accordance with the recommendations in the Guide for the Care and Use of Laboratory Animals of the National Institutes of Health. The protocol was approved by the Committee on the Ethics of Animal Experiments of Alexandria University, Egypt (Permit Number: 18261). A total of 480 one-d-old Cobb 500 broiler chicks of mixed sex were randomly assigned to 8 treatments, each treatment comprised 4 replicates with 15 birds each. The initial body weights of chicks are presented in Table 2. Four levels of CM ( 0 , $5,10$ and $20 \%)$ were used with or without Ultrazyme, a commercial cocktail enzyme supplement $(0,300 \mathrm{~g} /$ ton of diet) in a factorial design $4 \times 2$ in 8 dietary combinations. The enzyme complex used in this study was Ultrazyme commercial cocktail enzyme (Ultra Bio-Logics Inc., Rigaud Quebec Canada). It contains $\beta$ mannanase, xylanase, $\beta$-glucanase, $\alpha$-amylase, pectinase, phytase, proteases, lipase, amyloglycosidase, hemicellulose, acid phytase, acid phosphatase and pentosanase (Ultra Bio-Logics Inc., Rigaud Quebec Canada). The birds were fed starter mash diets until $21 \mathrm{~d}$ of age and followed by a finisher diet from $\mathrm{d} 22$ to $\mathrm{d} 42$ of age. Diets were targeted to meet NRC recommendations (NRC, 1994). The ingredients and chemical composition of the basal diets are presented in Table 1. Proximate analysis, which was conducted according to AOAC International (1995), showed no major deviation from calculated values. The used CM contained $2070 \mathrm{kcal} / \mathrm{kg} \mathrm{ME}, 36 \%$ crude protein, $12 \%$ crude fiber, $0.74 \%$ calcium, $0.34 \%$ available phosphorus, $1.9 \%$ lysine and $0.5 \%$ methionine. The 8 treatment diets were 1 ) $0 \% \mathrm{CM}$ diet with $0 \mathrm{~g} /$ ton Ultrazyme (CON), 2) $0 \% \mathrm{CM}$ diet with $300 \mathrm{~g} /$ ton Ultrazyme (T1), 3) $5 \% \mathrm{CM}$ diet with $0 \mathrm{~g} /$ ton of Ultrazyme (T2), 4) $5 \% \mathrm{CM}$ diet with $300 \mathrm{~g} /$ ton Ultrazyme (T3), 5) $10 \% \mathrm{CM}$ diet with $0 \mathrm{~g} /$ ton of Ultrazyme (T4), 6) $10 \% \mathrm{CM}$ diet with $300 \mathrm{~g} /$ ton Ultrazyme (T5), 7) $20 \% \mathrm{CM}$ diet with $0 \mathrm{~g} /$ ton of Ultrazyme (T6), and 8) $20 \% \mathrm{CM}$ diet with $300 \mathrm{~g} /$ ton Ultrazyme (T7). All birds were reared in the floor pens using wood shavings as litter. Temperature was adjusted at $32{ }^{\circ} \mathrm{C} \pm 2$ in the first wk then lowered $2{ }^{\circ} \mathrm{C}$ each successive week, and then maintained at $28{ }^{\circ} \mathrm{C} \pm 2$. Relative humidity was about 60 to $80 \%$. The chicks were vaccinated against Newcastle disease (ND). Access to feed (mash form) and water was provided on an ad libitum basis.

\subsection{Chicken Performance Measurements}

Body weight (BW) and feed intake were monitored on a pen basis weekly, while weight gain (BWG) and gain:feed ratio (G:F) values were consequently calculated. Mortality was also recorded on a daily basis in each pen (two birds died in CON, T4 and T6). There was no effect of treatment on the mortality rate. Chickens were killed by cervical dislocation at the end of the trial. Eight birds per treatment group (2/replicate) were randomly selected for tissue sampling and for determining carcass yield. They were defeathered, eviscerated and dressed. Abdominal fat, tissues of liver, gizzard, heart, proventriculus, thymus gland, spleen and bursa of Fabricius were collected by removing skin and connective tissue.

\subsection{Blood Sampling and Analysis}

At 14, 21 and $42 \mathrm{~d}$ of age, 8 birds from each treatment (2/replicate) were randomly selected for blood analysis. Blood samples were obtained from wing vein and directly aliquoted into 2-mL sterile vials and allowed to clot 
for $4 \mathrm{~h}$. After centrifugation $(20 \mathrm{~min}, 1500 \mathrm{rpm})$, the serum was aliquoted into $1-\mathrm{mL}$ vials and stored at $-20{ }^{\circ} \mathrm{C}$ for serum antibody measurements using haemagglutination inhibition test as described in Abou-Elkhair et al. (2014). The serum samples at $42 \mathrm{~d}$ of age were also used for total serum protein, albumin, globulin concentrations, serum glucose, cholesterol and triglyceride, glutamate oxaloacetate transaminase (GOT), glutamate pyruvate transaminase (GPT) and creatinine using commercially available kits (Biosystem S.A., Costa Brava, 30, Barcelona, Spain) according to manufacturer's instructions. The thyroid hormones, triiodothyronine (T3) and thyroxine (T4) are determined according to Beeler (1978) and Eastham (1985), respectively. At $42 \mathrm{~d}$ of age, another blood samples were aliquoted into $2 \mathrm{~mL}$ sterile vials containing anti-coagulant for measuring red blood cell count (RBC), hemoglobin content $(\mathrm{Hb})$ and packed cell volume (PCV). Total RBCs and total leukocyte counts (WBCs) were determined by haematocytometer according to Benjamin (1978). Hb was measured by Sahli's method according to Lucky (1977). Packed cell volume was determined according to the procedure of Benjamin (1978).

Table 1. Ingredients and nutrient composition (\% DM) of broiler starter and finisher rations

\begin{tabular}{|c|c|c|c|c|c|c|c|c|}
\hline \multirow{2}{*}{ Ingredient $(\%)$} & \multicolumn{4}{|c|}{ Broiler starter } & \multicolumn{4}{|c|}{ Broiler finisher } \\
\hline & $\mathrm{CON}$ & $5 \% \mathrm{CM}$ & $10 \% \mathrm{CM}$ & $20 \% \mathrm{CM}$ & $\mathrm{CON}$ & $5 \% \mathrm{CM}$ & $10 \% \mathrm{CM}$ & $20 \% \mathrm{CM}$ \\
\hline Yellow corn & 53.50 & 52.72 & 51.97 & 50.08 & 66.50 & 66.00 & 65.41 & 61.73 \\
\hline Soybean meal (48\%) & 34.38 & 29.33 & 24.36 & 15.17 & 24.00 & 18.50 & 13.28 & 7.01 \\
\hline Corn gluten & 5.32 & 6.10 & 6.75 & 7.70 & 3.00 & 4.10 & 5.00 & 4.05 \\
\hline Canola & - & 5.00 & 10.00 & 20.00 & - & 5.00 & 10.00 & 20.00 \\
\hline Corn oil & 2.50 & 2.57 & 2.66 & 2.95 & 2.52 & 2.48 & 2.48 & 3.59 \\
\hline Salt & 0.30 & 0.30 & 0.30 & 0.30 & 0.30 & 0.30 & 0.30 & 0.30 \\
\hline Dicalcium phosphate ${ }^{1}$ & 2.00 & 2.00 & 2.00 & 1.95 & 1.75 & 1.75 & 1.69 & 1.66 \\
\hline Premix $^{2}$ & 0.30 & 0.30 & 0.30 & 0.30 & 0.30 & 0.30 & 0.30 & 0.30 \\
\hline Limestone & 1.40 & 1.34 & 1.29 & 1.17 & 1.15 & 1.09 & 1.07 & 0.92 \\
\hline DL-Methionine ${ }^{3}$ & 0.13 & 0.13 & 0.12 & 0.12 & 0.20 & 0.18 & 0.18 & 0.18 \\
\hline L-Lysine-HCL ${ }^{4}$ & 0.17 & 0.21 & 0.25 & 0.26 & 0.28 & 0.30 & 0.34 & 0.34 \\
\hline \multicolumn{9}{|l|}{ Nutrients } \\
\hline Analyzed ME (kcal/kg) & 2976.83 & 2976.76 & 2976.40 & 2976.01 & 3096.31 & 3097.81 & 3097.50 & 3097.82 \\
\hline Analyzed Crude protein & 22.97 & 22.97 & 22.92 & 22.91 & 18.07 & 18.09 & 18.08 & 18.04 \\
\hline Calcium & 1.08 & 1.08 & 1.09 & 1.08 & 0.90 & 0.90 & 0.90 & 0.90 \\
\hline Available phosphorus & 0.52 & 0.52 & 0.52 & 0.52 & 0.45 & 0.45 & 0.45 & 0.45 \\
\hline Methionine & 0.52 & 0.52 & 0.52 & 0.52 & 0.51 & 0.50 & 0.50 & 0.49 \\
\hline Lysine & 1.29 & 1.29 & 1.30 & 1.26 & 1.13 & 1.11 & 1.11 & 1.11 \\
\hline
\end{tabular}

Note. $\mathrm{CON}=$ control basal diet; $\mathrm{CM}=$ canola meal.

${ }^{1}$ Dicalcium phosphate, $18 \%$ granular phosphate and $23 \%$ calcium.

${ }^{2}$ Supplied per kg of diet: vitamin A 12,000 IU, vitamin D3 3,000 IU, vitamin E $40 \mathrm{mg}$, vitamin K3 3 mg, vitamin B1 $2 \mathrm{mg}$, vitamin B2 $6 \mathrm{mg}$, vitamin B6 $5 \mathrm{mg}$, vitamin B12 $0.02 \mathrm{mg}$, niacin $45 \mathrm{mg}$, biotin $0.075 \mathrm{mg}$, folic acid 2 $\mathrm{mg}$, pantothenic acid $12 \mathrm{mg}$, manganese $100 \mathrm{mg}$, zinc $600 \mathrm{mg}$, iron $30 \mathrm{mg}$, copper $10 \mathrm{mg}$, iodine $1 \mathrm{mg}$, selenium $0.2 \mathrm{mg}$, cobalt $0.1 \mathrm{mg}$.

${ }^{3}$ DL-Methionine, Met AMINO ${ }^{\circledR}$ (DL-2-amino-4-(methyl-thio)-butane acid, DL-methionine, $\alpha$-amino-Y-methyloily acid) by Feed Grade $99 \%$ (EU).

${ }^{4}$ L-Lysine HCL 99\% (Feed Grade) L-Lysine: 78.0\% Min (Indonesia). 
Table 2. Body weight (BW), body weight gain (BWG), feed intake (FI) and feed conversion ratio (FCR) values of broiler chickens in response to diet supplemented with $\mathrm{CM}$ with or without multi-enzyme supplementation ${ }^{1}$

\begin{tabular}{|c|c|c|c|c|c|c|c|c|c|c|c|c|}
\hline \multirow{2}{*}{ Age } & \multicolumn{8}{|c|}{ Dietary treatment ${ }^{2}$} & \multirow{2}{*}{$S E M$} & \multicolumn{3}{|c|}{ P-value ${ }^{3}$} \\
\hline & $\mathrm{CON}$ & $\mathrm{T} 1$ & $\mathrm{~T} 2$ & $\mathrm{~T} 3$ & $\mathrm{~T} 4$ & $\mathrm{~T} 5$ & $\mathrm{~T} 6$ & $\mathrm{~T} 7$ & & $\mathrm{CM}$ & ENZ & $\mathrm{CM} \times \mathrm{ENZ}$ \\
\hline \multicolumn{13}{|l|}{0 day } \\
\hline BW, g & 39.40 & 38.99 & 39.01 & 38.88 & 39.13 & 39.01 & 39.12 & 38.96 & 0.44 & - & - & - \\
\hline \multicolumn{13}{|l|}{$D 0$ to 7} \\
\hline BW, g & $124.98^{\mathrm{bc}}$ & $143.11^{\mathrm{a}}$ & $114.67^{\mathrm{c}}$ & $140.61^{\mathrm{a}}$ & $116.04^{\mathrm{c}}$ & $130.87^{\mathrm{ab}}$ & $115.65^{\mathrm{c}}$ & $122.70^{\mathrm{bc}}$ & 6.97 & 0.02 & $<0.001$ & 0.28 \\
\hline BWG, g & $85.58^{\mathrm{c}}$ & $104.11^{\mathrm{a}}$ & $77.40^{\mathrm{d}}$ & $101.86^{\mathrm{a}}$ & $76.91^{\mathrm{d}}$ & $91.79^{\mathrm{b}}$ & $76.46^{\mathrm{d}}$ & $81.90^{\mathrm{c}}$ & 2.11 & $<0.001$ & $<0.001$ & $<0.001$ \\
\hline FI, $g$ & $112.15^{\mathrm{d}}$ & $115.51^{\mathrm{cd}}$ & $121.3^{\mathrm{c}}$ & $117.76^{\mathrm{cd}}$ & $121.64^{\mathrm{bc}}$ & $133.51^{\mathrm{a}}$ & $129.82^{\mathrm{ab}}$ & $122.15^{\mathrm{bc}}$ & 3.78 & $<0.001$ & 0.59 & 0.01 \\
\hline $\mathrm{G}: \mathrm{F}$ & $0.76^{\mathrm{b}}$ & $0.90^{\mathrm{a}}$ & $0.64^{\mathrm{cd}}$ & $0.87^{\mathrm{a}}$ & $0.63^{\mathrm{cd}}$ & $0.69^{\mathrm{c}}$ & $0.59^{\mathrm{c}}$ & $0.67^{\mathrm{c}}$ & 0.03 & $<0.001$ & $<0.001$ & 0.003 \\
\hline \multicolumn{13}{|l|}{ D 8 to 14} \\
\hline BW, g & $314.77^{\mathrm{abc}}$ & $337.72^{\mathrm{a}}$ & $307.65^{\mathrm{bc}}$ & $329.50^{\mathrm{ab}}$ & $303.43^{\text {bc }}$ & $316.70^{\mathrm{abc}}$ & $298.41^{\mathrm{c}}$ & $310.26^{\mathrm{bc}}$ & 12.54 & 0.07 & 0.005 & 0.89 \\
\hline BWG, g & $275.13^{b}$ & $298.68^{\mathrm{a}}$ & $270.45^{\mathrm{bc}}$ & $290.95^{\mathrm{a}}$ & $263.89^{c}$ & $277.64^{b}$ & $259.19^{\mathrm{c}}$ & $263.73^{c}$ & 4.95 & $<0.001$ & $<0.001$ & 0.07 \\
\hline FI, g & $285.71^{\mathrm{ab}}$ & $284.17^{\mathrm{ab}}$ & $286.73^{\mathrm{ab}}$ & $273.95^{\mathrm{b}}$ & $279.07^{\mathrm{ab}}$ & $268.84^{b}$ & $288.78^{\mathrm{ab}}$ & $299.51^{\mathrm{a}}$ & 8.79 & 0.03 & 0.44 & 0.26 \\
\hline $\mathrm{G}: \mathrm{F}$ & $0.96^{\mathrm{bc}}$ & $1.05^{\mathrm{a}}$ & $0.94^{\mathrm{c}}$ & $1.06^{\mathrm{a}}$ & $0.95^{\mathrm{c}}$ & $1.03^{\mathrm{ab}}$ & $0.90^{\mathrm{c}}$ & $0.88^{\mathrm{c}}$ & 0.04 & 0.001 & 0.002 & 0.09 \\
\hline \multicolumn{13}{|c|}{$D 15$ to 21} \\
\hline BW, g & 522.09 & 541.52 & 509.57 & 531.74 & 512.63 & 518.39 & 499.52 & 505.11 & 20.53 & 0.23 & 0.19 & 0.90 \\
\hline BWG, g & $207.57^{\mathrm{a}}$ & $201.65^{\mathrm{ab}}$ & $200.05^{\mathrm{ab}}$ & $202.27^{\mathrm{ab}}$ & $208.83^{\mathrm{a}}$ & $201.48^{\mathrm{ab}}$ & $205.81^{\mathrm{ab}}$ & $192.69^{\mathrm{b}}$ & 5.72 & 0.43 & 0.05 & 0.33 \\
\hline FI, g & $428.44^{b c}$ & $406.33^{\mathrm{c}}$ & $429.33^{\mathrm{bc}}$ & $447.73^{\mathrm{ab}}$ & $410.93^{c}$ & $462.04^{\mathrm{a}}$ & $442.08^{\mathrm{ab}}$ & $459.47^{\mathrm{ab}}$ & 13.55 & 0.03 & 0.03 & 0.01 \\
\hline $\mathrm{G}: \mathrm{F}$ & $0.49^{\mathrm{ab}}$ & $0.50^{\mathrm{ab}}$ & $0.47^{\mathrm{abc}}$ & $0.45^{\mathrm{bcd}}$ & $0.51^{\mathrm{a}}$ & $0.44^{\mathrm{cd}}$ & $0.47^{\mathrm{abc}}$ & $0.42^{\mathrm{d}}$ & 0.02 & 0.02 & 0.006 & 0.03 \\
\hline \multicolumn{13}{|c|}{ D 22 to 28} \\
\hline BW, g & 827.33 & 858.48 & 820.76 & 836.30 & 813.87 & 833.91 & 810.52 & 824.09 & 31.69 & 0.70 & 0.20 & 0.98 \\
\hline BWG, g & 317.62 & 308.94 & 311.18 & 315.90 & 301.81 & 315.79 & 306.62 & 312.76 & 15.29 & 0.96 & 0.61 & 0.77 \\
\hline FI, g & $468.22^{b c}$ & $444.66^{\mathrm{c}}$ & $472.78^{\mathrm{bc}}$ & $476.35^{\mathrm{bc}}$ & $489.64^{\mathrm{ab}}$ & $498.84^{\mathrm{ab}}$ & $518.77^{\mathrm{a}}$ & $477.77^{b c}$ & 14.94 & 0.004 & 0.10 & 0.10 \\
\hline G:F & 0.68 & 0.70 & 0.66 & 0.66 & 0.62 & 0.63 & 0.59 & 0.65 & 0.04 & 0.16 & 0.25 & 0.80 \\
\hline \multicolumn{13}{|c|}{ D 29 to 35} \\
\hline BW, g & $1351.23^{\mathrm{ab}}$ & $1431.48^{\mathrm{a}}$ & $1304.74^{\mathrm{b}}$ & $1332.11^{\mathrm{ab}}$ & $1293.66^{\mathrm{b}}$ & $1337.78^{\mathrm{ab}}$ & $1282.00^{\mathrm{b}}$ & $1332.35^{\mathrm{ab}}$ & 46.95 & 0.04 & 0.03 & 0.88 \\
\hline BWG, g & $514.17^{b}$ & $580.74^{\mathrm{a}}$ & $484.37^{b}$ & $496.27^{\mathrm{b}}$ & $480.28^{b}$ & $503.82^{\mathrm{b}}$ & $481.78^{b}$ & $497.95^{\mathrm{b}}$ & 15.23 & $<0.001$ & 0.001 & 0.08 \\
\hline FI, g & $596.74^{\mathrm{d}}$ & $635.81^{\mathrm{c}}$ & $636.84^{c}$ & $651.48^{c}$ & $687.99^{\mathrm{ab}}$ & $704.33^{\mathrm{a}}$ & $656.99^{\mathrm{bc}}$ & $699.71^{\mathrm{a}}$ & 16.18 & $<0.001$ & 0.003 & 0.50 \\
\hline $\mathrm{G}: \mathrm{F}$ & $0.86^{\mathrm{b}}$ & $0.91^{\mathrm{a}}$ & $0.76^{\mathrm{c}}$ & $0.76^{\mathrm{c}}$ & $0.70^{\mathrm{d}}$ & $0.72^{\text {cd }}$ & $0.73^{\mathrm{cd}}$ & $0.71^{\mathrm{cd}}$ & 0.02 & $<0.001$ & 0.31 & 0.21 \\
\hline \multicolumn{13}{|c|}{ D 36 to 42} \\
\hline $\begin{array}{l}\text { Final } \\
\text { BW, g }\end{array}$ & $1888.52^{\mathrm{ab}}$ & $1970.41^{\mathrm{a}}$ & $1808.37^{\mathrm{b}}$ & $1855.56^{\mathrm{b}}$ & $1802.27^{\mathrm{b}}$ & $1844.67^{b}$ & $1800.45^{\mathrm{b}}$ & $1838.59^{\mathrm{b}}$ & 55.86 & $<0.001$ & 0.06 & 0.94 \\
\hline BWG, g & $534.65^{\mathrm{ab}}$ & $548.55^{\mathrm{a}}$ & $502.92^{\mathrm{bc}}$ & $534.65^{\mathrm{ab}}$ & $510.23^{\mathrm{bc}}$ & $506.67^{\mathrm{bc}}$ & $517.31^{\mathrm{abc}}$ & $494.67^{\mathrm{c}}$ & 14.05 & 0.01 & 0.45 & 0.08 \\
\hline FI, g & $927.69^{\mathrm{a}}$ & $908.75^{\mathrm{ab}}$ & $911.53^{\mathrm{ab}}$ & $904.40^{\mathrm{ab}}$ & $866.71^{b}$ & $897.84^{\mathrm{ab}}$ & $880.98^{\mathrm{ab}}$ & $928.69^{\mathrm{a}}$ & 24.29 & 0.24 & 0.29 & 0.21 \\
\hline G:F & $0.58^{\mathrm{ab}}$ & $0.60^{\mathrm{a}}$ & $0.55^{\mathrm{ab}}$ & $0.59^{\mathrm{a}}$ & $0.59^{\mathrm{a}}$ & $0.56^{\mathrm{ab}}$ & $0.59^{\mathrm{a}}$ & $0.53^{\mathrm{b}}$ & 0.02 & 0.36 & 0.79 & 0.03 \\
\hline \multicolumn{13}{|l|}{ D 0 to 42} \\
\hline BWG, g & $1849.03^{\mathrm{b}}$ & $1938.55^{\mathrm{a}}$ & $1768.96^{\mathrm{c}}$ & $1840.04^{\mathrm{b}}$ & $1765.05^{\mathrm{c}}$ & $1805.39^{\mathrm{bc}}$ & $1770.71^{\mathrm{c}}$ & $1761.80^{\mathrm{c}}$ & 21.46 & $<0.001$ & $<0.001$ & 0.03 \\
\hline FI, g & $2818.95^{\mathrm{ab}}$ & $2795.24^{\mathrm{b}}$ & $2858.35^{\mathrm{ab}}$ & $2871.68^{\mathrm{ab}}$ & $2855.99^{\mathrm{ab}}$ & $2965.40^{\mathrm{a}}$ & $2917.42^{\mathrm{ab}}$ & $2986.30^{\mathrm{a}}$ & 70.52 & 0.06 & 0.25 & 0.56 \\
\hline G:F & $0.66^{\mathrm{b}}$ & $0.69^{\mathrm{a}}$ & $0.62^{\mathrm{bcd}}$ & $0.64^{\mathrm{bc}}$ & $0.62^{\mathrm{bcd}}$ & $0.61^{\mathrm{cd}}$ & $0.61^{\mathrm{cd}}$ & $0.59^{\mathrm{d}}$ & 0.02 & $<0.001$ & 0.33 & 0.13 \\
\hline
\end{tabular}

Note. ${ }^{1}$ Each value represents the mean of four replicates ( 15 birds/replicate). Within rows, means followed by different letters are significantly different at $P<0.05$.

${ }^{2} \mathrm{CON}, 0 \% \mathrm{CM}$ diet with $0 \mathrm{~g}$ /ton Ultrazyme; T1, $0 \% \mathrm{CM}$ diet with $300 \mathrm{~g} /$ ton Ultrazyme; $\mathrm{T} 2,5 \% \mathrm{CM}$ diet with 0 $\mathrm{g} /$ ton of Ultrazyme; T3, 5\% CM diet with $300 \mathrm{~g}$ /ton Ultrazyme; T4, 10\% CM diet with $0 \mathrm{~g} /$ ton of Ultrazyme; T5, $10 \% \mathrm{CM}$ diet with $300 \mathrm{~g} /$ ton Ultrazyme; T6, 20\% CM diet with $0 \mathrm{~g} /$ ton of Ultrazyme; T7, 20\% CM diet with $300 \mathrm{~g} /$ ton Ultrazyme.

${ }^{3} \mathrm{CM}$, canola meal; ENZ, multi-enzyme supplement. 
Table 3. Effect of dietary supplementation with different levels of canola with or without enzyme supplement on carcass traits ( $\%$ body weight) at $42 \mathrm{~d}$ of age in broiler chickens ${ }^{1}$

\begin{tabular}{|c|c|c|c|c|c|c|c|c|c|c|c|c|}
\hline \multirow{2}{*}{ Parameter } & \multicolumn{8}{|c|}{ Dietary treatments $^{2}$} & \multirow{2}{*}{ SEM } & \multicolumn{3}{|c|}{ P-value ${ }^{3}$} \\
\hline & $\mathrm{CON}$ & $\mathrm{T} 1$ & $\mathrm{~T} 2$ & $\mathrm{~T} 3$ & $\mathrm{~T} 4$ & T5 & T6 & $\mathrm{T} 7$ & & $\mathrm{CM}$ & ENZ & $\mathrm{CM} \times \mathrm{ENZ}$ \\
\hline Dressing & 72.50 & 72.45 & 73.74 & 72.66 & 73.11 & 70.56 & 72.94 & 72.81 & 2.25 & 0.84 & 0.41 & 0.85 \\
\hline Liver & 2.38 & 2.41 & 2.59 & 2.52 & 2.11 & 2.24 & 2.07 & 2.14 & 0.25 & 0.07 & 0.75 & 0.95 \\
\hline Gizzard & 1.90 & 1.94 & 1.72 & 1.64 & 1.68 & 1.69 & 1.88 & 1.52 & 0.24 & 0.26 & 0.33 & 0.47 \\
\hline Proventriculus & 0.35 & 0.37 & 0.40 & 0.37 & 0.40 & 0.35 & 0.38 & 0.36 & 0.04 & 0.89 & 0.37 & 0.70 \\
\hline Heart & 0.55 & 0.51 & 0.57 & 0.49 & 0.53 & 0.46 & 0.49 & 0.45 & 0.06 & 0.43 & 0.07 & 0.97 \\
\hline Spleen & 0.20 & 0.16 & 0.23 & 0.21 & 0.17 & 0.20 & 0.21 & 0.16 & 0.07 & 0.79 & 0.55 & 0.83 \\
\hline Thymus & 0.24 & 0.33 & 0.30 & 0.16 & 0.36 & 0.26 & 0.36 & 0.39 & 0.11 & 0.32 & 0.58 & 0.41 \\
\hline Bursa & 0.069 & 0.043 & 0.046 & 0.049 & 0.050 & 0.052 & 0.054 & 0.046 & 0.01 & 0.56 & 0.13 & 0.10 \\
\hline Abdominal fat & 1.90 & 1.14 & 1.26 & 1.55 & 1.12 & 1.15 & 1.25 & 1.38 & 0.49 & 0.73 & 0.75 & 0.46 \\
\hline
\end{tabular}

Note. ${ }^{1}$ Each value represents the mean of four replicates ( 2 birds/replicate). Within rows, means followed by different letters are significantly different at $P<0.05$.

${ }^{2} \mathrm{CON}, 0 \% \mathrm{CM}$ diet with $0 \mathrm{~g} /$ ton Ultrazyme; T1, $0 \% \mathrm{CM}$ diet with $300 \mathrm{~g} /$ ton Ultrazyme; $\mathrm{T} 2,5 \% \mathrm{CM}$ diet with 0 $\mathrm{g} /$ ton of Ultrazyme; T3, 5\% CM diet with $300 \mathrm{~g}$ /ton Ultrazyme; T4, $10 \% \mathrm{CM}$ diet with $0 \mathrm{~g}$ /ton of Ultrazyme; T5, $10 \% \mathrm{CM}$ diet with $300 \mathrm{~g} /$ ton Ultrazyme; T6, 20\% CM diet with $0 \mathrm{~g} /$ ton of Ultrazyme; T7, 20\% CM diet with $300 \mathrm{~g} /$ ton Ultrazyme.

${ }^{3} \mathrm{CM}$, canola meal; ENZ, multi-enzyme supplement.

\subsection{Economic Measurements}

Total variable costs included the price of chicks and feed (CM and enzyme prices), labor costs, value of veterinary medicaments (vaccine, disinfectant costs and veterinary supervision), litter costs and miscellaneous cost (water, fuel and electrolyte costs). It was estimated per LE during the cycle of the experiment. Total fixed costs included the costs of building and equipment depreciation (L.E). The depreciation of the building and equipment was calculated according to the following equations (Saad et al., 2014):

Value of building depreciation for each chick $=[($ value of building (L.E)/No. of years $(20 \mathrm{yrs}$.) $) /$ No. of cycle per year]/Total number of chicks.

Value of equipment depreciation for each chick $=[($ value of equipment $($ L.E $) /$ No. of years $(5 \mathrm{yrs})$.$) / No. of cycle$ per year]/Total number of chicks.

Total cost was calculated from the summation of total fixed cost and total variable cost. Total returns were the sum of litter sale and chicken sale. Chicken sale value $=$ body weight at end of the experiment $\left(6^{\text {th }} \mathrm{wk}\right) \times$ gram price. Net profit was the net income using the following equation: Net profit $=$ Total return - Total cost.

\subsection{Statistical Analysis}

Experimental data were subjected to ANOVA using the GLM procedure using SPSS 22 statistical package (SPSS Ltd., Surrey, UK version 22) as a $4 \times 2$ factorial, with the main effects of $\mathrm{CM}$ and enzyme, and the $\mathrm{CM} \times$ enzyme interaction. Significant means among variables were separated by Duncan's multiple range test at the 5 $\%$ level of significance.

\section{Results}

\subsection{Growth Period}

The effects of feeding CM at a level of $0,5,10$ and $20 \%$ with or without multi-enzyme addition during weekly periods on BW, BWG, feed intake (FI), G:F ratio was summarized in Table 2. During the whole experimental period of $6 \mathrm{wk}$, significant $\mathrm{CM} \times$ enzyme interaction $(P=0.03)$ was observed for BWG indicated that inclusion of $\mathrm{CM}$ at a level of 5 and $10 \%$ without multi-enzyme supplement and at a level of $20 \%$ with or without multi-enzyme addition decreased BWG compared to CON. Additionally, multi-enzyme supplementation to corn-soybean based diet improved final BWG compared to the control group. However, during the experimental period of $6 \mathrm{wk}(0-42 \mathrm{~d}$ of age), there was no $\mathrm{CM} \times$ enzyme interaction for FI or G:F. Additionally, we did not observe any difference in final $\mathrm{BW}$ at $42 \mathrm{~d}$ of age between treatments and control. 


\subsection{Carcass Traits}

The effects of feeding different $\mathrm{CM}$ levels with or without multi-enzyme supplementation on carcass characteristics were presented in Table 3. Dressing percentages and relative weight of liver, gizzards, proventriculus, heart, spleen, thymus, bursa, and abdominal fat were not affected by CM, enzyme supplementation or their interaction.

\subsection{Hematology and Serum Metabolites and Hormones}

The effect of dietary supplementation of different level of CM with or without multi-enzyme on RBCs count, Hb, $\mathrm{PCV}$, total protein, albumin, globulin, triglycerides, total cholesterol, GOT, GPT, creatinine, T3 and T4 are shown in Table 4. Significant CM $\times$ enzyme interactions were noticed for RBCs $(P<0.001)$ and $\mathrm{HB}(P<0.05)$, a differential pattern of changes between the groups. Broilers on T5 $(10 \% \mathrm{CM}+$ multi-enzyme $)$ had higher serum total protein concentration $(P=0.003)$; however, broilers fed $\mathrm{T} 2(5 \% \mathrm{CM})$ had lower serum globulin concentration $(P<0.001)$ compared to CON. Chickens fed on T1 (basal diet + multi-enzyme), T3 (5\% CM + multi-enzyme), T5 (10\% CM + multi-enzyme) and T7 (20\% CM + multi-enzyme) had lower serum triglycerides (TG) content compared to the control chickens. A tend for $\mathrm{CM} \times$ enzyme interaction $(P=0.05)$ was found in serum total cholesterol (TC) concentration characterized by lower TC in groups fed on T3 and T5 diets, indicating that inclusion of $\mathrm{CM}$ at a level of $5 \%$ or $10 \%$ with multi-enzyme addition decreased serum TC compared to CON. Inclusion of $\mathrm{CM}$ at a level of 5, 10 and 20\% with enzyme supplementation decreased serum GOT compared to the CON and enzyme-unsupplemented groups $(\mathrm{CM} \times$ enzyme, $P=0.01)$. Chicks fed diet supplemented with $5 \% \mathrm{CM}$ plus multi-enzyme showed lower serum GPT than the control chicks. Diets supplemented with $\mathrm{CM}$ at 5,10 and $20 \%$ had higher serum creatinine compared to $\mathrm{CON}(\mathrm{P}<0.05)$. For serum $\mathrm{T} 3$, we observed lower $\mathrm{T} 3$ in broilers on $\mathrm{T} 4, \mathrm{~T} 6$ and $\mathrm{T} 7$, while, chickens on $\mathrm{T} 1$ and $\mathrm{T} 3$ had higher $\mathrm{T} 3$ compared to CON. No significant differences were found in serum T4 between treatments and CON.

\subsection{Antibody Titer}

Table 5 summarized the effects of feeding different CM levels with or without multi-enzyme supplementation on antibody titer $(\mathrm{Ab})$ at $\mathrm{d}$ 14, 21, and 42 of age. No significant differences were found in Ab titer at 14 and $21 \mathrm{~d}$ of age; however, at $42 \mathrm{~d}$ of age, there was a significant decrease in Ab in diets supplemented with 5, 10 and 20\% CM compared to the control group.

\subsection{Economic Profitability}

Total cost, total return and net profit for this experiment was presented in Table 6. The analysis of variance of the data revealed that there was a highly significant difference between the control group and other supplemented in the total cost value. Meanwhile, there was a slight significant difference between the control group and the different treatments in the total return and the net profit for this experiment.

\section{Discussion}

\subsection{Growth Performance}

An increase in the dietary level of CM resulted in a reduction in BW gain of birds. The reduced BW gain as a result of the increased dietary level of CM could have been attributed to high content of fiber and NSP in CM (Payvastagan et al., 2012). Additionally, this may partly contribute to increased liver metabolic activities (Woyengo et al., 2011). In the current study, the increased blood level of GOT and GPT in CM supplemented groups may indicate increased hepatic metabolic activities in these birds. Thus, the higher metabolic activity of the liver due to dietary inclusion of CM suggests increased utilization of dietary energy and various nutrients, including amino acids, minerals and B-complex vitamins for maintenance at the expense of growth (Parke \& Ioannides, 1981; Bauman et al., 1988; Woyengo et al., 2011), leading to reduced BW gain. Newkirk and Classen (2002) also observed a decrease in BW gain of broilers as a result of dietary inclusion of solvent-extracted CM. Our results were supported by the findings of Larbier and Leclercq (1994) and Gheorghe et al. (2005). Inclusion of $\mathrm{CM}$ at a level of 5 and $10 \%$ with multi-enzyme supplementation increased BWG compared to un-supplemented CM diets. It was reported previously that multi-enzyme supplementation to CM based diets improved the quality of CM (Slominski \& Campbell, 1990; Campbell et al., 2001; Sariçiçek et al., 2005).

The lack of difference in FI between treatments and control may probably attribute to low GLS content in CM that used in the current study. Leeson et al. (1987) reported that a complete replacement of soybean meal with $\mathrm{CM}(<30 \mu \mathrm{mol} / \mathrm{g}$ GLS $)$ had no effect on FI of chickens. Min et al. (2009) reported that the inclusion of CM in the broiler diets from 0 to $25 \%$ decreased FI and BW gain in younger birds. Additionally, Payvastagan et al. (2012) observed that BW gain and feed conversion ratio were impaired by the addition of CM at $20 \%$ of the diet during 1 to $21 \mathrm{~d}$ of age. Our results differ from others that reported better feed conversion ratio in broiler 
chickens fed diet containing 25\% CM (Naseem et al., 2006), and to Baloch et al. (2003) who observed no adverse effect on the performance of chicks fed diet supplemented with extracted de-hulled canola rapeseed up to $20 \%$. Different results may be related to the different levels of GLS in the diets. Together, the results described above suggest that replacement of SBM with CM in poultry diet at a level of 5, 10 and $20 \%$ of the diet with multi-enzyme supplementation can be effectively used without any adverse effect on broiler growth performance.

\subsection{Carcass Traits}

Inclusion of $\mathrm{CM}$ at a level of 5, 10 and $20 \%$ of the diet with or without enzyme supplementation did not affect carcass traits. These results agreed with previous reports (Sariçiçek et al., 2005; Mushtaq et al., 2007). On the contrary, Kocher et al. (2001) found that different CM levels did not affect dressing percentages, but enzyme supplementation appeared to increase dressing percentage. Woyengo et al. (2011) observed that increasing the $\mathrm{CM}$ level from 0 to $40 \%$ in broiler diet did not affect the relative weight of heart, thyroid and kidney but increased liver weight. In the current study, there were no differences in the relative weight of spleen, thymus gland and bursa of Fabricius among the treatment groups. Recently, Gopinger et al. (2014) reported that birds fed diets contained 0 and $10 \%$ of $\mathrm{CM}$ had greater breast weight than those fed on $40 \% \mathrm{CM}$, but there were no differences for leg and wing weights and yields among birds fed with different levels of $\mathrm{CM}(0,10,20,30$ and $40 \%$ ). Taken together, these findings suggest that the addition of CM up to $20 \%$ in broiler diet had no adverse effect on carcass traits or lymphoid organs.

\subsection{Hematology and Blood Parameters}

The present study showed a differential pattern of changes between the groups regarding RBCs and $\mathrm{Hb}$. Payvastagan et al. (2012) observed no significant effect from using different levels of CM on $\mathrm{Hb}$ and PCV. Furthermore, Ramesh et al. (2006) and Woyengo et al. (2011) reported that higher level of CM in broiler diet had no any significant effect on blood $\mathrm{Hb}$ and hematocrit. Our data did not reveal a significant clear effect of using different level of CM on serum total protein, albumin and globulin. Szymeczko et al. (2010) reported that using different levels of rape seeds in broiler diet did not affect protein metabolism indices, total protein and albumin. In addition, Pearson et al. (1983) recorded higher plasma total protein and albumin in broilers fed diet supplemented with $500 \mathrm{~g}$ rapeseed meal $/ \mathrm{kg}$ of broiler diet. Further, they stated that these changes were due to extra thyroidal toxicity.

All levels of CM used in the present study increased serum TG without any significant effect on TC compared to CON. Similar to our findings, Szymeczko et al. (2010) reported that broilers fed on rapeseeds diets had higher level of TG compared to the control group and no significant effect was found on serum TC. Kamran Azad et al. (2009) did not show a significant effect of canola seeds used in broiler diets in the amount of 7.5 and $15 \%$ on serum TG and TC. On other hand, Pearson et al. (1983) stated that rapeseed meal in higher level significantly increased TC and decreased TG. In the current study, enzyme supplementation significantly decreased serum TG and TC to physiological norms specified for broiler chickens compared to enzyme-unsupplemented groups.

Inclusion of $\mathrm{CM}$ at a level of 10 and $20 \%$ in broiler diet reduced serum concentration of $\mathrm{T} 3$, in agreement with Taraz et al. (2006). However, Ramesh et al. (2006) observed that T3 and T4 levels were not influenced by the inclusion of rapeseed meal. The actions of thyroid hormones are mostly dependent on binding to nuclear receptors. It was suggested previously that anti-thyroid compounds of rapeseed meal could destroy these receptors (Schöne et al., 2006), and alter outer ring de-iodination of T4 in the peripheral tissues (Darras et al., 2000). Therefore, the observed lower serum concentration of T3 in broilers fed on a CM based diet may be due to the above mentioned mechanism. Reductions of $\mathrm{T} 3$ concentration may reduce body weight gain of broiler, because T3 can stimulate the transcription of growth hormone mRNA and growth hormone synthesis in the pituitary gland (Yen, 2001). No significant difference was observed in T4 in CM levels, which may be due to the physiological equilibrium in the thyroid gland of chicks after the $6^{\text {th }}$ wk of age. In agreement with this result, Taraz et al. (2006) reported no difference in T4 from using rapeseed meal in broiler diet. 
Table 4. Effect of dietary supplementation with different levels of canola with or without enzyme supplement on blood composition at $42 \mathrm{~d}$ of age in broiler chickens ${ }^{1}$

\begin{tabular}{|c|c|c|c|c|c|c|c|c|c|c|c|c|}
\hline \multirow{2}{*}{ Parameter } & \multicolumn{8}{|c|}{ Dietary treatments ${ }^{2}$} & \multirow{2}{*}{$S E M$} & \multicolumn{3}{|c|}{ P-value ${ }^{3}$} \\
\hline & $\mathrm{CON}$ & $\mathrm{T} 1$ & $\mathrm{~T} 2$ & $\mathrm{~T} 3$ & $\mathrm{~T} 4$ & $\mathrm{~T} 5$ & T6 & $\mathrm{T} 7$ & & $\mathrm{CM}$ & ENZ & $\mathrm{CM} \times \mathrm{ENZ}$ \\
\hline $\operatorname{RBCs}\left(10^{6} / \mathrm{mm}^{3}\right)$ & $1.90^{\mathrm{b}}$ & $1.85^{\mathrm{cd}}$ & $1.82^{\mathrm{de}}$ & $1.91^{\mathrm{b}}$ & $1.95^{\mathrm{a}}$ & $1.87^{\mathrm{c}}$ & $1.80^{\mathrm{e}}$ & $1.83^{\mathrm{cd}}$ & 0.01 & $<0.001$ & 0.52 & $<0.001$ \\
\hline $\mathrm{Hb}, \mathrm{g} / 100 \mathrm{~mL}$ & $9.63^{\mathrm{bc}}$ & $10.47^{\mathrm{abc}}$ & $9.88^{\mathrm{bc}}$ & $10.53^{\mathrm{ab}}$ & $10.75^{\mathrm{a}}$ & $10.07^{\mathrm{abc}}$ & $9.99^{\mathrm{bc}}$ & $9.71^{\mathrm{c}}$ & 0.32 & 0.15 & 0.77 & 0.03 \\
\hline PCV, \% & $29.14^{\mathrm{c}}$ & $30.12^{\mathrm{ab}}$ & $29.46^{\mathrm{bc}}$ & $29.66^{\mathrm{bc}}$ & $30.12^{\mathrm{ab}}$ & $30.60^{\mathrm{a}}$ & $29.76^{\mathrm{bc}}$ & $29.93^{\mathrm{b}}$ & 0.28 & 0.004 & 0.005 & 0.20 \\
\hline Total protein, $\mathrm{g} / \mathrm{dL}$ & $5.73^{\mathrm{b}}$ & $6.28^{\mathrm{ab}}$ & $5.54^{\mathrm{b}}$ & $6.28^{\mathrm{ab}}$ & $5.75^{\mathrm{b}}$ & $6.53^{\mathrm{a}}$ & $5.76^{\mathrm{b}}$ & $5.98^{\mathrm{ab}}$ & 0.32 & 0.65 & 0.003 & 0.61 \\
\hline Albumin, $\mathrm{g} / \mathrm{dL}$ & $3.47^{\mathrm{b}}$ & $3.44^{\mathrm{b}}$ & $3.95^{\mathrm{a}}$ & $3.41^{\mathrm{b}}$ & $3.53^{\mathrm{b}}$ & $3.71^{\mathrm{ab}}$ & $3.72^{\mathrm{ab}}$ & $3.50^{\mathrm{b}}$ & 0.16 & 0.30 & 0.09 & 0.05 \\
\hline Globulin, g/dL & $2.27^{\mathrm{ab}}$ & $2.83^{\mathrm{a}}$ & $1.59^{\mathrm{c}}$ & $2.87^{\mathrm{a}}$ & $2.22^{\mathrm{abc}}$ & $2.82^{\mathrm{a}}$ & $2.03^{\mathrm{bc}}$ & $2.48^{\mathrm{ab}}$ & 0.29 & 0.29 & $<0.001$ & 0.20 \\
\hline $\mathrm{TG}, \mathrm{mg} / \mathrm{dL}$ & $167.65^{\mathrm{b}}$ & $147.80^{\mathrm{d}}$ & $172.07^{\mathrm{ab}}$ & $150.85^{\mathrm{cd}}$ & $174.73^{\mathrm{a}}$ & $151.32^{\mathrm{cd}}$ & $174.89^{\mathrm{a}}$ & $155.93^{\mathrm{c}}$ & 3.01 & 0.02 & $<0.001$ & 0.75 \\
\hline $\mathrm{TC}, \mathrm{mg} / \mathrm{dL}$ & $174.18^{\mathrm{ab}}$ & $160.33^{d}$ & $173.30^{\mathrm{ab}}$ & $165.70^{c}$ & $175.61^{\mathrm{ab}}$ & $165.60^{\mathrm{c}}$ & $177.59^{\mathrm{a}}$ & $172.28^{\mathrm{b}}$ & 2.01 & 0.001 & $<0.001$ & 0.05 \\
\hline GOT, U/100 mL & $90.96^{\mathrm{bc}}$ & $62.40^{\mathrm{e}}$ & $98.54^{\mathrm{a}}$ & $72.19^{\mathrm{d}}$ & $95.74^{\mathrm{ab}}$ & $76.84^{\mathrm{d}}$ & $101.44^{\mathrm{a}}$ & $85.90^{\mathrm{c}}$ & 2.68 & $<0.001$ & $<0.001$ & 0.01 \\
\hline GPT, U/100 mL & $68.22^{\mathrm{bc}}$ & $68.35^{\mathrm{c}}$ & $70.34^{\mathrm{bc}}$ & $78.47^{\mathrm{a}}$ & $73.40^{\mathrm{ab}}$ & $68.75^{\mathrm{bc}}$ & $74.17^{\mathrm{ab}}$ & $70.10^{\mathrm{bc}}$ & 3.06 & 0.01 & 0.48 & 0.03 \\
\hline Creatinine, $\mu \mathrm{mol} / \mathrm{L}$ & $2.23^{\mathrm{b}}$ & $2.23^{\mathrm{b}}$ & $3.15^{\mathrm{a}}$ & $2.30^{\mathrm{b}}$ & $3.18^{\mathrm{a}}$ & $2.63^{\mathrm{ab}}$ & $3.15^{\mathrm{a}}$ & $2.77^{\mathrm{ab}}$ & 0.31 & 0.02 & 0.01 & 0.31 \\
\hline $\mathrm{T} 3, \mathrm{ng} / \mathrm{mL}$ & $74.45^{\mathrm{b}}$ & $81.30^{\mathrm{a}}$ & $73.47^{\mathrm{b}}$ & $80.53^{\mathrm{a}}$ & $68.40^{\mathrm{c}}$ & $75.19^{\mathrm{b}}$ & $61.53^{\mathrm{d}}$ & $68.40^{\mathrm{c}}$ & 1.40 & $<0.001$ & $<0.001$ & 0.99 \\
\hline $\mathrm{T} 4, \mathrm{ng} / \mathrm{mL}$ & $1.95^{\mathrm{abc}}$ & $1.89^{\mathrm{c}}$ & $2.00^{\mathrm{abc}}$ & $2.02^{\mathrm{abc}}$ & $1.91^{\mathrm{bc}}$ & $2.03^{\mathrm{abc}}$ & $2.10^{\mathrm{a}}$ & $2.07^{\mathrm{ab}}$ & 0.07 & 0.04 & 0.81 & 0.35 \\
\hline
\end{tabular}

Note. ${ }^{1}$ Each value represents the mean of four replicates ( 2 birds/replicate). Within rows, means followed by different letters are significantly different at $P<0.05$.

${ }^{2} \mathrm{CON}, 0 \% \mathrm{CM}$ diet with $0 \mathrm{~g} /$ ton Ultrazyme; T1, $0 \% \mathrm{CM}$ diet with $300 \mathrm{~g} /$ ton Ultrazyme; T2, 5\% CM diet with 0 $\mathrm{g} /$ ton of Ultrazyme; T3, 5\% CM diet with $300 \mathrm{~g} /$ ton Ultrazyme; T4, 10\% CM diet with $0 \mathrm{~g} /$ ton of Ultrazyme; T5, $10 \% \mathrm{CM}$ diet with $300 \mathrm{~g} /$ ton Ultrazyme; T6, 20\% CM diet with $0 \mathrm{~g} /$ ton of Ultrazyme; T7, 20\% CM diet with $300 \mathrm{~g} /$ ton Ultrazyme.

${ }^{3} \mathrm{CM}$, canola meal; ENZ, multi-enzyme supplement.

The data of the present trial indicate that the inclusion of CM in broiler diet by 5,10 and $20 \%$, significantly increased serum creatinine compared to the control group. This indicates higher protein muscular metabolism. The available literature lacks results confirming the influence of different levels of rapeseeds on muscular metabolism indices. However Szymeczko et al. (2010) reported that the concentration of creatinine was lower in birds fed the diets with the highest level of rapeseeds.

No significant differences were found in antibody titer against ND in age of 14 and 21; however, in $42 \mathrm{~d}$, there was a significant decrease in antibody titer in all CM groups compared to control. Mushtaq et al. (2007) reported no difference in terms of antibody titer against ND was observed with higher levels of CM (20 and $30 \%)$. 
Table 5. Effect of dietary supplementation with different levels of canola with or without enzyme supplement on antibody titer at 14, 21 and $42 \mathrm{~d}$ of age in broiler chickens ${ }^{1}$

\begin{tabular}{llll}
\hline \multirow{2}{*}{ Treatments $^{2}$} & \multicolumn{3}{c}{ Antibody titer $\left(\log _{2}\right)$} \\
\cline { 2 - 4 } & $14 \mathrm{~d}$ & $21 \mathrm{~d}$ & $42 \mathrm{~d}$ \\
\hline CON & $2.78^{\mathrm{abc}}$ & $4.12^{\mathrm{ab}}$ & $5.08^{\mathrm{ab}}$ \\
$\mathrm{T} 1$ & $3.16^{\mathrm{a}}$ & $5.32^{\mathrm{a}}$ & $5.72^{\mathrm{a}}$ \\
$\mathrm{T} 2$ & $2.80^{\mathrm{abc}}$ & $3.60^{\mathrm{b}}$ & $3.54^{\mathrm{e}}$ \\
T3 & $2.72^{\mathrm{abc}}$ & $4.40^{\mathrm{ab}}$ & $4.90^{\mathrm{abc}}$ \\
T4 & $2.54^{\mathrm{bc}}$ & $3.54^{\mathrm{b}}$ & $3.74^{\mathrm{de}}$ \\
T5 & $2.88^{\mathrm{ab}}$ & $4.16^{\mathrm{ab}}$ & $4.90^{\mathrm{abc}}$ \\
T6 & $2.30^{\mathrm{c}}$ & $3.54^{\mathrm{b}}$ & $3.98^{\mathrm{cde}}$ \\
T7 & $2.52^{\mathrm{bc}}$ & $4.18^{\mathrm{ab}}$ & $4.66^{\mathrm{bcd}}$ \\
SEM & 0.24 & 0.54 & 0.46 \\
\hline Canola & 0.02 & 0.09 & 0.002 \\
Enzyme & 0.08 & 0.005 & $<0.001$ \\
Canola×Enzyme & 0.52 & 0.86 & 0.61 \\
\hline
\end{tabular}

Note. ${ }^{1}$ Each value represents the mean of four replicates ( 2 birds/replicate). Within columns, means followed by different letters are significantly different at $P<0.05$.

${ }^{2} \mathrm{CON}, 0 \% \mathrm{CM}$ diet with $0 \mathrm{~g} /$ ton Ultrazyme; T1, $0 \% \mathrm{CM}$ diet with $300 \mathrm{~g} /$ ton Ultrazyme; $\mathrm{T} 2,5 \% \mathrm{CM}$ diet with 0 $\mathrm{g} /$ ton of Ultrazyme; T3, 5\% CM diet with $300 \mathrm{~g} /$ ton Ultrazyme; T4, 10\% CM diet with $0 \mathrm{~g}$ /ton of Ultrazyme; T5, $10 \% \mathrm{CM}$ diet with $300 \mathrm{~g} /$ ton Ultrazyme; T6, 20\% CM diet with $0 \mathrm{~g} /$ ton of Ultrazyme; T7, $20 \% \mathrm{CM}$ diet with $300 \mathrm{~g} /$ ton Ultrazyme.

\subsection{Economic Profitability}

From the obtained results, we found that there was a highly significant difference between the control group and groups with different treatment in the value of total costs. As the highest significant increase $(\mathrm{P}<0.001)$ appears in the group of T7 that fed on a diet contains $20 \%$ CM with enzyme was $(13.51 \mathrm{LE} / \mathrm{bird})$ among all groups. Moreover, the lowest significant value appears in T4 treated with $10 \% \mathrm{CM}$ was $(13.12 \mathrm{LE} / \mathrm{bird})$. While the control group which has no any supplementation represent $(13.23 \mathrm{LE} / \mathrm{bird})$. Total return also differs significantly among control and the other different treated groups. The highest total return obtained in the group of T1 that fed on BD supplemented with multi-enzyme supplementation, it was $(27.38 \mathrm{LE} /$ bird $)$ and the lowest total return was (25.08 LE/bird) that observed in T4. While, the total return of control group was $(26.18 \mathrm{LE} / \mathrm{bird})$. Furthermore, the net profit of all treated groups showed a slight significant improvement as the highest net profit obtained in T1 that fed on basal diet supplemented with enzyme $(14.08 \mathrm{LE} / \mathrm{bird})$ While the lowest value at the T6 treated with $20 \% \mathrm{CM}(11.88 \mathrm{LE} / \mathrm{bird})$. The net profit from control group was $(12.95 \mathrm{LE} / \mathrm{bird})$. This result was in disagreement with (Onu et al., 2011) who reported that addition of enzyme to broiler meal will reduce the cost of feed intake and the cost of feed, however, agreed with (Santin et al., 2003) who found that addition of supplement to broiler ration showed a slight increase in the net revenue. 
Table 6. Effect of dietary supplementation with different levels of canola with or without enzyme supplement on total cost, total return and net return of broiler chickens ${ }^{1}$

\begin{tabular}{llll}
\hline \multirow{2}{*}{ Treatments $^{2}$} & \multicolumn{3}{c}{ Economic profitability } \\
\cline { 2 - 4 } & Total cost & Total return & Net return \\
\hline CON & $13.23^{\text {cd }}$ & $26.18^{\text {ab }}$ & $12.95^{\mathrm{ab}}$ \\
T1 & $13.30^{\mathrm{bc}}$ & $27.38^{\mathrm{a}}$ & $14.08^{\mathrm{a}}$ \\
$\mathrm{T} 2$ & $13.20^{\mathrm{de}}$ & $25.65^{\mathrm{b}}$ & $12.45^{\mathrm{b}}$ \\
$\mathrm{T} 3$ & $13.33^{\mathrm{b}}$ & $26.05^{\mathrm{ab}}$ & $12.71^{\mathrm{ab}}$ \\
$\mathrm{T} 4$ & $13.12^{\mathrm{e}}$ & $25.08^{\mathrm{b}}$ & $11.97^{\mathrm{b}}$ \\
$\mathrm{T} 5$ & $13.50^{\mathrm{a}}$ & $25.61^{\mathrm{b}}$ & $12.11^{\mathrm{b}}$ \\
T6 & $13.26^{\mathrm{bcd}}$ & $25.14^{\mathrm{b}}$ & $11.88^{\mathrm{b}}$ \\
T7 & $13.51^{\mathrm{a}}$ & $25.50^{\mathrm{b}}$ & $11.99^{\mathrm{b}}$ \\
SEM & 0.05 & 0.69 & 0.70 \\
\hline Canola & $<0.001$ & 0.02 & 0.01 \\
Enzyme & $<0.001$ & 0.07 & 0.24 \\
Canola $\times$ Enzyme & $<0.001$ & 0.85 & 0.74 \\
\hline
\end{tabular}

Note. ${ }^{1}$ Each value represents the mean of four replicates ( 15 birds/replicate). Within columns, means followed by different letters are significantly different at $P<0.05$.

${ }^{2} \mathrm{CON}, 0 \% \mathrm{CM}$ diet with $0 \mathrm{~g}$ /ton Ultrazyme; T1, $0 \% \mathrm{CM}$ diet with $300 \mathrm{~g} /$ ton Ultrazyme; $\mathrm{T} 2,5 \% \mathrm{CM}$ diet with 0 $\mathrm{g} /$ ton of Ultrazyme; T3, 5\% CM diet with $300 \mathrm{~g}$ /ton Ultrazyme; T4, 10\% CM diet with $0 \mathrm{~g} /$ ton of Ultrazyme; T5, $10 \% \mathrm{CM}$ diet with $300 \mathrm{~g} /$ ton Ultrazyme; T6, 20\% CM diet with $0 \mathrm{~g} /$ ton of Ultrazyme; T7, 20\% CM diet with $300 \mathrm{~g} /$ ton Ultrazyme.

\section{Conclusions}

In conclusion, the inclusion of CM in broiler diets ( $0-42 \mathrm{~d}$ of age) as a substitute for SBM, at a level of 5,10 and $20 \%$, had no adverse effects on growth performance and carcass traits, but it decreased serum antibody titer against ND and increased serum TG, GOT, GPT creatinine and T3 of broilers at $42 \mathrm{~d}$ of age. Additionally, multi-enzyme supplementation to CM based diets decreased serum TC, TG, GOT and GPT concentration. These findings support the need for carbohydrase enzyme complexes in broiler diet containing CM.

\section{Acknowledgements}

The Authors extend their appreciation to the Scientific Research at Damanhour and Sadat City Universities for funding the work through the research group project. The authors gratefully appreciate the assistance of the Food and Feed Safety laboratory staff at Faculty of Veterinary Medicine, Damanhour University.

\section{References}

Abou-Elkhair, R., Ahmed, H. A., \& Selim, S. (2014). Effects of black pepper (Piper nigrum), turmeric powder (Curcuma longa) and coriander seeds (Coriandrum sativum) and their combinations as feed additives on growth performance, carcass traits, some blood parameters and humoral immune response of broiler chickens. Asian-Australas. J. Anim. Sci., 27, 847-854. http://dx.doi.org/10.5713/ajas.2013.13644

Annison, G. (1991). Relationship between the levels of soluble nonstarch polysaccharides and the apparent metabolizable energy of wheats assayed in broiler chickens. J. Agric. Food Chem., 39, 1252-1256. http://dx.doi.org/10.1021/jf00007a011

AOAC. (1995). Official Methods of Analysis (16th ed.). Association of Official Analytical Chemists, Arlington, Virginia, USA.

Baloch, G. M., Solangi, A. A., Wagan, M. P., \& Tahira, M. (2003). Efficiency of canola meal in broiler ration. $J$. Anim. Vet. Ad., 2, 138-142.

Bauman, P. F., Smith, K., \& Bray, T. M. (1988). The effect of dietary protein and sulfur amino acids on hepatic glutathione concentration and glutathione-dependent enzyme activities in the rat. Can J Physiol Pharmacol., 
66, 1048-1052. http://dx.doi.org/10.1139/y88-171

Beeler, M. F. (1978). Interpretation in Clinical Chemistry. ASCP, 446-453.

Bell, J. M. (1993). Factors affecting the nutritional value of canola meal: A review. Can. J. Anim. Sci., 73, 679-697. http://dx.doi.org/10.4141/cjas93-075

Benjamin, M. M. (1978). Outline of Veterinary Clinical Pathology (3rd ed.). Iowa State University Press. Ames, Iowa.

Campbell, L. D., Liang, D., Slominski, B. A., \& Guenter, W. (2001). Nutritive value of enzyme pre-treated canola meal (pp. 334-342). Proceedings International Symposium on rapeseed Science. April, 19-23. Wuhan, The People's Republic of China.

Chesson, A. (1993). Feed enzymes. Anim. Feed Sci. Technol., 45, 65-97. http://dx.doi.org/10.1016/0377-8401(93)90072-R

Darras, V. M., Van der Geyten, S., \& Kühn, E. R. (2000). Thyroid hormone metabolism in poultry. Biotechnol. Agron. Soc. Environ., 4, 13-20.

Eastham, R. D. (1985). Biochemical values in clinical medicine (7th ed.). Bristol England John Wright \& Sons, Ltd.

Gheorghe, A., Ciurescu, G., \& Moldovan, I. (2005). Productive effect of replacing the dietary soybean meal by various levels of rapeseed meal in broiler diets supplemented with enzyme preparations. Archiva Zootechnica., 8, 107-112.

Gopinger, E., Xavier, E. G., Lemes, J. S., Moraes, P. O., Elias, M. C., \& Roll, V. F. B. (2014). Carcass yield and meat quality in broilers fed with canola meal. Br. Poult. Sci., 55, 817-823. http://dx.doi.org/10.1080/00071668.2014.980394

Ikegami, S., Tsuchihashi, F., Harada, H., Tsuchihashi, N., Nishide, E., \& Innami, S. (1990). Effect of viscous indigestible polysaccharides on pancreatic-bilary secretion and digestive organs in rats. J. Nutr., 120, 335-360.

Kamran Azad, S., Rahimi, S., \& Karimi Torshizi, M. A. (2009). Effect of dietary oil seeds on n-3 fatty acid enrichment, performance parameters and humoral immune response of broiler chickens. Iran. J. Vet. Res., $10,158-165$.

Khajali, F., Tahmasebi, M., Hassanpour, H., Akbari, M. R., Qujeq, D., \& Wideman, R. F. (2011). Effects of supplementation of canola meal-based diets with arginine on performance, plasma nitric oxide, and carcass characteristics of broiler chickens grown at high altitude. Poult. Sci., 90, $2287-2294$. http://dx.doi.org/10.3382/ps.2011-01618

Kocher, A., Choct, M., Morrisrose, L., \& Broz, J. (2001). Effects of enzyme supplementation on the replacement value of canola meal for soybean meal in broiler diets. Australian J. Agric. Res., 52, 447-452. http://dx.doi.org/10.1071/AR00072

Kocher, A., Choct, M., Porter, M. D., \& Broz, J. (2000). The effects of enzyme addition to broiler diets containing high concentrations of canola or sunflower meal. Poult. Sci., 79, 1767-1774. http://dx.doi.org/10.1093/ps/79.12.1767

Larbier, M., \& Leclercq, B. (1994). Nutriția şi alimentația păsărilor. Alutus, Bucuresti.

Leeson, S., Atteh, J. O., \& Summers, J. D. (1987). The replacement value of canola meal for soybean meal in poultry diets. Can. J. Anim. Sci., 67, 151-158. http://dx.doi.org/10.4141/cjas87-017

Lucky, Z. (1977). Methods for the diagnosis of Fish diseases. Amerind publishing Co., PVT, LTD, New Delhi, Bombay, Calcutta and New York.

Mikulski, D., Jankowski, J., Zdunczyk, Z., Juskiewicz, J., \& Slominski, B. (2012). The effect of different dietary levels of rapeseed meal on growth performance, carcass traits, and meat quality in turkeys. Poult. Sci., 91, 215-223. http://dx.doi.org/10.3382/ps.2011-01587

Min, Y. N., Hancock, A., Yan, F., Lu, C., Coto, C., Karimi, A., ... Waldroup, P. W. (2009). Use of combinations of canola meal and distillers dried grains with solubles in broiler starter diets. J. Appl. Poult. Res., 18, $725-733$. http://dx.doi.org/10.3382/japr.2009-00050

Mushtaq, T., Sarwar, M., Ahmad, G., Mirza, M. A., Nawaz, H., Mushtaq, M. M., \& Noreen, U. (2007). Influence of canola meal-based diets supplemented with exogenous enzyme and digestible lysine on performance, 
digestibility, carcass, and immunity responses of broiler chickens. Poult. Sci., 86, 2144-2151. http://dx.doi.org/10.1093/ps/86.10.2144

Naseem, M. Z., Khan, S. H., \& Yousaf, M. (2006). Effect of feeding various levels of canola meal on the performance of broiler chicks. J. Anim. Pl. Sci., 16(3-4).

National Research Council. (1994). Nutrient Requirements of Poultry (9th ed.). National Academy Press, Washington, DC., USA.

Newkirk, R. (2009). Canola meal: Feed industry guide. Retrieved from http://www.canolacouncil. org/media/516716/canola_meal_feed_guide_english.pdf

Onu, P. N., Madubuike, F. N., Onu, D. O., \& Ekenyem, B. U. (2011). Performance and economic analysis of broiler starter chicks fed enzyme supplemented sheep manure-based diets. J. Agric. Biol. Sci., 6, 14-19.

Parke, D. V., \& Ioannides, C. (1981). The role of nutrition in toxicology. Ann. Rev. Nutr., 1, 207-234. http://dx.doi.org/10.1146/annurev.nu.01.070181.001231

Payvastagan, S., Farhoomand, P., Shahrooze, R., Delfani, N., \& Talatapeh, A. (2012). The effects of different levels of canola meal and copper on performance, susceptibility to ascites and plasma enzyme activities in broiler chickens. Ann. Biol. Res., 3, 5252-5258.

Pearson, A. W., Greenwood, N. M., Butler, E. J., \& Fenwick, G. R. (1983). Biochemical changes in layer and broiler chickens when fed on a high-glucosinolate rapeseed meal. Br. Poult. Sci., 24, 417-427. http://dx.doi.org/10.1080/00071668308416756

Ramesh, K. R., Devegowda, G., \& Khosravinia, H. (2006). Effects of enzyme addition to broiler diets containing varying levels of double zero rapeseed meal. Asian-Australas. J. Anim. Sci., 19, 1354-1360. http://dx.doi.org/10.5713/ajas.2006.1354

Saad, T. T., Atallah, S. T., \& El-Bana, S. A. (2014). Fish diseases and its economic effect on Egyptian fish farms. J. Agric. Food. Tech., 4(5), 1-6.

Santin, E., Mairoka, A., \& Macari, M. (2001). Performance and intestinal mucosa development of broiler chickens fed diets containing Saccharomyces cerevisiae cell wall. J. Appl. Poult. Res., 10, 236-244. $\mathrm{http} / / / \mathrm{dx}$.doi.org/10.1093/japr/10.3.236

Sariçiçek, B. Z., Kiliç, Ü., \& Garipoğlu, A. V. (2005). Replacing soybean meal (SBM) by canola meal (CM): The effects of multi-enzyme and phytase supplementation on the performance of growing and laying quails. Asian-Australas. J. Anim. Sci., 18, 1457-1463. http://dx.doi.org/10.5713/ajas.2005.1457

Schöne, F., Jahreis, G., Richter, G., \& Lange, R. (2006). Evaluation of rapeseed meals in broiler chicks: Effect of iodine supply and glucosinolate degradation by myrosinase or copper. J. Sci. Food Agric., 61, 245-252. http://dx.doi.org/10.1002/jsfa.2740610218

Simbaya, J., Slominski, B. A., Guenter, W., Morgan, A., \& Campbell, L. D. (1996). The effects of protease and carbohydrase supplementation on the nutritive value of canola meal for poultry: In vitro and in vivo studies. Anim. Feed Sci. Technol., 61, 219-234. http://dx.doi.org/10.1016/0377-8401(95)00939-6

Slominski, B. A., \& Campbell, L. D. (1990). Non-starch polysaccharides of canola meal: Quantification, digestibility in poultry and potential benefit of dietary enzyme supplementation. J. Sci. Food Agric., 53, 175-184. http://dx.doi.org/10.1002/jsfa.2740530205

SPSS. (2013). IBM SPSS Statistics for Windows (Version 22.0). Armonk, NY: IBM Corp.

Szymeczko, R., Topoliński, T., Burlikowska, K., Piotrowska, A., Bogusławska-Tryk, M., \& Błaszyk, J. (2010). Effect of different levels of rape seeds in the diet on performance, blood and bone parameters of broiler chickens. J. Cent. Eur. Agric., 11, 393-400. http://dx.doi.org/10.5513/JCEA01/11.4.843

Taraz, Z., Jalali, S. M. A., \& Rafeie, F. (2006). Effects of replacement of soybean meal with rapeseed meal on organs weight, some blood biochemical parameters and performance of broiler chicks. Int. J. Poult. Sci., 5, 1110-1115. http://dx.doi.org/10.3923/ijps.2006.1110.1115

Tripathi, M., \& Mishra, A. (2007). Glucosinolates in animal nutrition: A review. Anim. Feed Sci. Technol., 132, 1-27. http://dx.doi.org/10.1016/j.anifeedsci.2006.03.003

Woyengo, T. A., Kiarie, E., \& Nyachoti, C. M. (2011). Growth performance, organ weights, and blood parameters of broilers fed diets containing expeller-extracted canola meal. Poult. Sci., 90, 2520-2527. http://dx.doi.org/10.3382/ps.2011-01436 
Yen, P. M. (2001). Physiological and molecular basis of thyroid hormone action. Physiol. Rev., 81, 1097-1142.

\section{Copyrights}

Copyright for this article is retained by the author(s), with first publication rights granted to the journal.

This is an open-access article distributed under the terms and conditions of the Creative Commons Attribution license (http://creativecommons.org/licenses/by/3.0/). 